\title{
Interpreting Intervention
}

Craig Scott

Osgoode Hall Law School of York University

\section{Source Publication:}

Canadian Yearbook of International Law. Volume 39 (2001), p. 333-369.

Follow this and additional works at: https://digitalcommons.osgoode.yorku.ca/scholarly_works

Part of the International Humanitarian Law Commons, International Law Commons, and the Military, War, and Peace Commons

\section{c) (i) (9)}

This work is licensed under a Creative Commons Attribution-Noncommercial-No Derivative Works 4.0 License.

\section{Recommended Citation}

Scott, Craig. "Interpreting Intervention." Canadian Yearbook of International Law 39 (2001): 333-369.

This Article is brought to you for free and open access by the Faculty Scholarship at Osgoode Digital Commons. It has been accepted for inclusion in Articles \& Book Chapters by an authorized administrator of Osgoode Digital Commons. 


\title{
Feature Article / Article vedette
}

\section{Interpreting Intervention}

\author{
CRAIG SCOTT
}

\section{INTRODUCTION}

Since the North Atlantic Treaty Organization's (NATO) interNention in Yugoslavia during the Kosovo crisis, a number of leading actors have been pushing for the general recognition of the lawfulness of "humanitarian intervention" in certain circumstances and in the absence of express authorization from the United Nations Security Council. Various normative phenomena have begun to emerge in the 1990s, which suggest that the practice of some actors (both state and non-state, including the United Nations SecretaryGeneral) and the relative acquiescence of others have combined to

Craig Scott, Associate Professor of Law and Associate Dean of Research and Graduate Studies, Osgoode Hall Law School, York University, Toronto. The present article is an elaboration of an address delivered to the "Think Canada" Conference on Issues for the Twenty-First Century: Think Peace and Security, Tokyo, Japan, April 17, 2001. It was written in May 2001 and has deliberately not been substantively revised since then in light of either the events of September 11, 2001, or of the report released in December 2001 by the International Commission on Intervention and State Sovereignty [hereinafter ICISS]. See ICISS, The Responsibility to Protect (Ottawa: International Development Research Centre, 2001), which can also be found at <http://www.iciss.gc.ca/report-e.asp> (last visited April 1, 2002). Indeed, the author has refrained from reading any of the report until after the editing process for the present article has ended. It was felt by both the author and the Yearbook editors that the analysis and approach of the present article, as written in the spring of 2001 , should stand on their own as contributions to the debates that have taken on a new meaning since the article was written, notably the interconnecting normative debates on humanitarian intervention flowing from the ICISS report and the debates on security-related intervention in the aftermath of September 11 . Thank you to Graham Boswell for his able research assistance, to Stella Harmantas for her critical proofing, and to Shedrack Agbakwa for help with the final revisions.

* Author's Note, August 5, 2010:The publisher's copy-editor erroneously'corrected' the text without the author's approval, after the proofs stage, by inserting "American" in place of "Atlantic." This 'correction' has been corrected here, but the correction is shown clearly as a departure from the original, as published, 
produce a widening and deepening view that a Security Council consensus sufficient to produce a binding resolution explicitly authorizing the use of force is, while desirable, not in all contexts necessary for an intervention to be considered lawful. The primary contexts in which these phenomena have played themselves out have been: the use of military force against Iraq as a means of enforcing compliance with the United Nations weapons inspection regime for that country as well as a means of enforcing no-fly zones over areas of northern and southern Iraq; the intervention of a regional organization known as the Economic Community of West African States (ECOWAS) into Liberia; and the war launched by NATO against Yugoslavia as a result of the crisis in Kosovo. One irony of these developments is that they have occurred in tandem with a quantum leap in Security Council activities in the 199os an evolution of international governance in the peace and security field that one might have expected would have led to even less acceptance of any freedom of states to circumvent the Council. In the face of this irony, the mounting sense of the acceptability of either threatening or using force without express authorization of the Security Council seems, in part, explicable because of the fact that some protagonists have begun to settle on a series of justifications that manage to present interventions not as acts of blatant side-stepping but rather as acts that have been undertaken in some form of collaboration with the Council. Alongside these intertwined political and moral discourses, we are also witnessing the rising influence of various legal theories of implied authorization and strong purposive arguments that contend that legal validity can be generated through decision-making processes that fulfill the collectivist spirit of the Security Council's scheme, even as they depart from the letter of the Charter of the United Nations (Charter) text. ${ }^{1}$

Receptivity to the aforementioned emergent justifications has arguably been bolstered by four developments that sometimes complement, but also sometimes exist in tension with, the apparent resurgence of Security Council authority since the end of the Cold War. First of all, there has been a rise in the discursive influence of various actors in "transnational civil society," and the successful adoption (many would say appropriation) by state and interstate actors of humanitarianism is a powerful normative language in transnational relations. Second, a certain triumphalism and

\footnotetext{
${ }^{1}$ Charter of the United Nations, June 26, 1945, Can. T.S. 1945 No. 7, 59 Stat. 1031,145 U.K.F.S. 805. art/2(7) [hereinafter Charter].
} 
resurgent messianism has fuelled the impatience of the world's hegemon, the United States, and its in-law, the United Kingdom, with any "obstructionism" by other P-5 powers (notably China and Russia but also France) as well as positions taken by states such as India, which are dismissed as self-serving and/or illiberal. Third, the economic levers available to the more affluent states, in particular, the United States, and the formal criteria for participation in the global economic order (notably, admission to the World Trade Organization) have made many states much more likely to accede to "lobbying" from affluent states. Fourth, non-formalist, open-textured theories of international law have come into their own, such as the contextual and process-oriented approaches associated with the "New Haven School." The congeniality of such theories of international law has developed partly for reasons that are internal to discourse in the scholarly community of international law and international relations and partly because these theories fit better with the agendas of the actors described in the above sentences.

Against this backdrop, the purpose of this article is to relate this evolution of an implicit-authorization rationale to comments recently made in a keynote speech by Lloyd Axworthy about the decision-making process in which he participated as then-Minister for Foreign Affairs for Canada during the Kosovo crisis. ${ }^{3}$ Axworthy noted how Canada's Department of Foreign Affairs and International Trade (DFAIT) considered whether, at the point at which NATO military intervention was imminent, authority to intervene could be interpretively distilled from the existing body of Kosovorelated Security Council resolutions. He noted that he and his advisors considered that these resolutions were indeed not sufficient. Accordingly, Canada gave its consent to the military initiatives of NATO, having arrived at the view that such use of force was illegal under the current state of international law. I agree with this conclusion and also respect the fact that Canada more or less decided that the issue of intervention over Kosovo was, therefore, one of compelling moral justification for acting unlawfully. The tragic choice faced by former Foreign Minister Axworthy has

${ }^{2}$ For a classic and accessible introduction to this approach, see Michael Reisman, "International Lawmaking: A Process of Communication" (1981) 75 Proceedings of the American Society of International Law 101.

3 Lloyd Axworthy, "Keynote Speech" ("Think Canada" Conference on Issues for the Twenty-First Century: Think Peace and Security, Tokyo, Japan, April 17 , 2001) [unpublished]. 
clearly contributed to a real concern on his part, as well as on the part of other leading politicians, such as the minister of foreign affairs of the Netherlands, to see the legal framework changed so as to eventually secure recognition of the power, even the duty, to intervene in situations of extreme humanitarian necessity. ${ }^{4}$

What I would like to suggest is that the Canadian government's inquiry - as to whether authority could be read into the existing complex of Security Council resolutions - is itself significant because of its apparent willingness to entertain the possibility that express authorization may not in all circumstances be necessary. Despite the highly dangerous dimensions of such a theory - a theory that, I would note, is embraced by the United States and to some extent by the United Kingdom - it is worth considering whether evolving re-interpretation may not be the preferable way to think about accommodating humanitarian intervention to the greatest extent possible within the UN Charter itself, by resolutely insisting lawfulness does require Security Council authorization and, at the same time, being more flexible in determining what constitutes authorization. In other words, can and should the complex of words and conduct of Security Council members and closely related actors, such as the Secretary-General, sometimes be reasonably interpreted as clearly welcoming and, to that extent, authorizing intervention despite the failure to adopt a binding resolution that explicitly says so?

Before moving to the heart of my argument, I feel compelled to say that I do have profound misgivings about the process of Charter re-interpretation as it is currently evolving due to the overbearing role of the United States, and of the West in general, and due to the relative lack of critical self-awareness of many states that their silence and pragmatic acquiescence is feeding into a normative realignment of Charter peace and security law. Greater transparency and less manipulation is needed in order for the process I am about to describe to be something that I would feel comfortable treating as a legitimate form of evolutionary constitutional reform. However, that said, I do see what is starting to happen as being a more sophisticated way of understanding the relationship

${ }^{4}$ See Lloyd Axworthy, Minister of Foreign Affairs of Canada, "Human Rights and Humanitarian Intervention: Notes for an Address (2000/29)" (Washington, DC, June 16, 2000) [unpublished]; Jozias van Aartsen, Foreign Minister of the Netherlands, "Opening Remarks," in International Peace Academy, "Humanitarian Action: International Peace Academy Report," report of a Conference (New York: International Peace Academy, 2000), Annex II, at 12. 
of legality and morality in global governance on peace and security issues than an approach that views things in either one of two other ways: (1) an approach that sees legality as a static question of reading the Charter text textually and, as a corollary, formal Charter amendment as the only way to create greater responsiveness of the international community to humanitarian crises around the world; or (2) an approach that pushes us to view the ethics of intervention as being about either moral breaches of constitutional (Charter) law or as being about the endorsement of a theory of exceptionalism whereby the world's leading military power simply asserts the power to advance the purposes of a "just" world order as it sees fit when it sees fit, while denying that this power is a general legal permission for other states, notably regional powers such as India, Brazil, Russia, China, Indonesia, or Nigeria, to do the same. ${ }^{5}$

Having lodged this major caveat, I nonetheless view the justificatory process surrounding Kosovo and also Iraq as a process that can be provisionally embraced as an opportunity to channel our energies towards a more collectivist process of re-interpreting the Charter in a way that stands a chance of attracting a sufficiently general consensus - a consensus that is far from existing at the moment. In this respect, while I will not have time to elaborate, it is worth outlining at this stage how a variety of kinds of collaborations might provide a process-oriented basis for harmonizing law, politics, and morality. Such collaborative processes, first of all, help to get us as close to legality as possible by promoting overarching legal values through engagement in collective decision-making, which may not satisfy the precise legal-formal requirements of the Charter but which, nonetheless, adheres quite closely to its spirit. Second, quite apart from rubbing shoulders with legality, collectivist consensus-seeking processes necessarily involve putting a premium on persuasion and a corresponding merger of self-interest with a broader consensus on the general interest to be served by advocated courses of action. Related to this moral benefit, such processes also help to mitigate the potential for abuse and thus help increase the legitimacy portion of a course of action to the extent that external observers can feel reasonably confident that a decision was not taken as a pure assertion of power. Third, the foregoing benefits interact with questions of political effectiveness.

${ }^{5}$ On US normative exceptionalism, see, on the academic front, Michael Glennon, "American Hegemony in an Unplanned World Order" (2000) 5 Journal of Conflict and Security Law 3; and, on the journalistic front, Christopher Hitchens, "Rogue Nation U.S.A.," Mother Jones, May/June 2001 , at 32. 
Widespread support enhances the credibility of collective resolve to act forcefully, which enhances individual diplomatic efforts - for example, by allowing diplomatic actors (including the SecretaryGeneral) to warn offending regimes about the need to change their conduct without directly threatening them. Credibility of the resolve to act at the international level is further enhanced to the extent that the collective processes of decision-making help deepen political will at the domestic level and lessen the chances that electorally sensitive governments will be fickle in the strength and longevity of their support for forceful measures as a result of the waxing and waning of the tolerance of the domestic electorate for an involvement in foreign military action.

These introductory comments in mind, I now proceed to a core example of the process of Charter interpretation as it has occurred during the 1990 s with respect to Iraq. It is not claimed that the use of military force in the Iraq context has been an example of compelling humanitarian necessity (indeed, concomitant use of economic sanctions on Iraq has contributed significantly to a humanitarian disaster in that country) but, rather, that it is an example of more traditional perceptions of necessity because of an extreme security threat. ${ }^{6}$

\section{IraQ as Precursor to Kosovo}

Security Council Resolution 678 authorized states cooperating with Kuwait to use "all necessary means" to force Iraq's withdrawal from Kuwait and also to "restore international peace and security in the area." After Operation Desert Storm succeeded in ousting Iraqi forces from Kuwait, the Security Council adopted Resolution $687 .{ }^{8}$ It imposed a cease-fire on all combatants and also established the United Nations Special Commission (UNSCOM), which was

${ }^{6}$ I do not wish to deny that the concerns about the production and possible re-use of some weapons of mass destruction by the current, or a future, Iraqi regime does not have a humanitarian component. It clearly does. The goal of preventing a capacity to use such weapons as chemical and bacteriological warheads is clearly a legitimate humanitarian concern from a preventative perspective. The use of the term "weapons of mass destruction" includes mass death.

7 UN Security Council Resolution 678 (1990), November 29, 1990, text can be accessed online at <http://www.un.org/Docs/scres/1990/678e.pdf > (last visited March 28, 2002).

${ }^{8}$ UN Security Council Resolution 687 (1991), April 3, 1991, text can be accessed online at <http://www.un.org/Docs/scres/1991/687e.pdf> (last visited March 28,2002 ). 
the United Nations's most ambitious and sophisticated monitoring regime to date. UNSCOM was charged with the mandate of discerning Iraq's continuing weapons of mass destruction (WMD) programs and verifying that its weaponry and weapon-making capacity had been destroyed by Iraq. A comprehensive sanctions regime was also associated with the weapons-inspection regime. The removal of sanctions was the intended prize for Iraq once it had complied with all requirements to eliminate its WMD capacity. In relatively short order, Iraq resisted the UNSCOM inspections regime, employing a gamut of tactics to do so. These tactics included engaging in periodic games of brinkmanship with the United States and the United Kingdom whenever the latter states made clear that they were willing to employ military force as a response to Iraq's noncompliance with Resolution 687. Starting with the United States, a number of states, including Japan, began to advance or quietly accept an interpretive theory that contended that if the inspection requirements of Resolution 687 were "materially breached," then the cease-fire mandated by Resolution 687 could reciprocally be considered by states that had been cooperating with Kuwait as having been suspended. ${ }^{9}$ The consequence of this suspension of the requirement to respect the cease-fire would be, according to this theory, that the original Resolution 678 would become applicable again, including, in particular, the authorization to use "all necessary means ... to restore international peace and security in the area." There are all kinds of problems with the plausibility of this interpretive theory of the relationship between Resolutions 687 and 678 , not least being the chronological problems of Resolution 678 having envisioned a restoration of peace and security. Such a mandate, quite clearly, did not contemplate the revision of the status quo ante through a comprehensive disarmament program aimed at Iraq.

There is clearly a crucial issue as to whether (and, if so, how) an evolutionary interpretive meaning can be accorded to Resolution 678 so as to render it capable of bouncing back into shape as a consequence of any serious non-compliance with Resolution 687 by Iraq. However, my focus will be on a less-straightforward interpretive evolution within Security Council practice, which has (arguably) transpired despite what initially seemed to be the vocal

\footnotetext{
${ }^{9}$ This is an argument by analogy with the provisions on material breach of treaties: see Article 6o of the Vienna Convention on the Law of Treaties, January 27, 1969,1155 U.N.T.S. 331 .
} 
resistance of a permanent member of the Security Council to the interpretation in question. My narrative looks at the effect of warnings from the Security Council about the future "serious" or "severest" consequences of continuing non-compliance with Council resolutions. Although the immediate purpose of this upcoming discussion is more sociological than normative, the normative issue raised by my account is profound and warrants highlighting at this point: should the international legal community accept warnings of unspecified consequences from unspecified quarters as being sufficient to authorize states to act militarily in order to force compliance, without having first received any further instructions from the Council? Answering this question will be part of what animates the discussion later in this article when I seek to present a framework for thinking about the role the General Assembly must play in validating claims that implicit authorizations have emerged from the Security Council.

Before proceeding, two preliminary points must be made in order to prepare the reader for the nuanced nature of the normative signalling games in which states engage in the context of negotiating the space between the Charter's multilateral monopoly over the use of force other than in self-defence and the reality of unilateral or oligopolistic judgments being made by states wishing, or simply being willing, to use force to secure (what are presented) as the ends of the international community as a whole. First of all, central to my narrative will be the linguistic acts of two actors - the President of the Security Council and the Secretary-General — who are not expressly accorded an authoritative role with respect to interpreting the meaning of Security Council resolutions, let alone a central one. A key part of the signalling game at stake in the Iraq context has been the relationship between their statements and the formally binding collective acts of the Security Council in the form of resolutions. Second, I have been using the term "warning" to describe the statements emanating from the Security Council, and I will continue to use this term. However, I do so advisedly, because a significant part of the ambiguity surrounding the import of these statements is precisely whether or not they are best characterized as warnings or, instead, as threats. The difference hinges on the relationship between the actor(s) uttering the threat or warning and the actor(s) that are meant to be understood as being prepared to act on that threat or warning should the triggering conditions (indicated in the threat or warning) be met. The actor who utters a threat will be the actor that will make good on the threat, 
whereas the actor acting on a warning will be different from the actor issuing the warning. If it is tolerably clear that the members of the Security Council at any given time intend the expressions "serious consequences" or "severest consequences" to refer to, or at least to include, military measures (in a manner not dissimilar to how "all necessary means," as used in Resolution 678 , is now understood as a term of art for an express authorization to use force), it is by no means clear in which of at least three possible ways the Security Council wishes to be understood. The options are (1) as a threat that the Security Council, seized of the matter, will return to it and subsequently expressly authorize military measures; (2) as a warning that there are some states that will take matters into their own hands and adopt the military option (leaving this as a factual statement with no normative stance being taken towards this eventuality one way or the other); or (3) as a hybrid in which threat and warning join hands in such a way that the signal is that some states will adopt this option and that, if this happens, the Council will treat this conduct as lawful. It is the third validating signal that transmits a warning simultaneously as a threat - and, put differently, as an implicit authorization of the Council for states to act as its agent. I now turn to how it is that the combined role - even tag-team performance - of the Security Council president and the Secretary-General may have helped convert a threat of future action by the Security Council (the first signal) and a warning of future action by unspecified states (the second signal) into this third hybrid signal.

In early 1998, Secretary-General Kofi Annan went, on his own initiative, to Baghdad in order to seek concessions from Iraq that would have the effect of avoiding military strikes that were being threatened by the United States in particular. After Annan's return to New York in March 1998 with the United Nations-Iraq Memorandum of Understanding (MOU), many in the United States' foreign policy apparatus were incensed at his intervention, which had made it politically impossible at that time for the United States to go ahead with its military strikes - strikes that were viewed as being necessary in light of a persistent pattern of bad faith noncompliance by Iraq with the UNSCOM regime. ${ }^{10}$ To soften the sting, the Security Council adopted Resolution 1154 , in which it was stated that the "severest consequences" would result should Iraq

${ }^{10}$ United Nations - Iraq Memorandum of Understanding, February 23, 1998, (1998) 37 I.L.M. 501 . 
not live up to the MOU that it had just entered into with SecretaryGeneral Annan. ${ }^{11}$ The employment of this phrase seemed designed to tap into a discursive precedent that seems to have become instantiated as a linguistic convention in prior Security Council practice vis-à-vis Iraq, albeit not within, but rather parallel to, Security Council resolutions - in the form of statements of the president of the Council. Note that, in this regard, the presidency of the Security Council rotates amongst the different member states of the Council, with the president's statements being issued, by commonly accepted practice, only where the president of the Security Council of the time is confident that the statement in question reflects the consensus of the Security Council members.

On at least two occasions prior to 1998 , in 1993 and then again in 1997 , the Security Council president used similar, while not identical, language when Iraq was warned of "serious consequences" should it continue to fail to comply with Security Council demands for cooperation with UNSCOM. ${ }^{12}$ Following the 1993 warning (indeed, only two days later), the United Kingdom, the United States, and France went on to bomb Iraqi targets in southern Iraq. ${ }^{13}$ Whether or not any firm consensus had evolved by 1998 amongst the permanent members of the Security Council with respect to at least a de facto acquiescence in recourse to military action following a presidential warning of "serious consequences," the aforementioned 1998 warning did seem to represent a qualitative shift in the Council's linguistic signalling practice, since it differed in two significant respects from those of 1993 and 1997 - in both form and content. In terms of form, the 1998 warning was inserted within Security Council Resolution 1154 itself, rather than being articulated at one step removed through the formally non-binding vehicle of presidential notes or statements. As for the

${ }^{11}$ See, UN Security Council Resolution 1154 (1998), March 2, 1998, at para. 3, text can be accessed online at <http://www.un.org/Docs/scres/1998/ sres1 154.htm> (last visited March 28, 2002): "The Security Council ... [s] tresses that compliance ... is necessary for the implementation of resolution 687 (1991), but that any violation would have severest consequences for Iraq."

12 Note by the President of the Security Council, UN Doc. S/25091 (1993). In 1997, the president said: "The Security Council warns of the serious consequences of Iraq's failure to comply immediately and fully." Statement of the President of the Security Council, UN Doc. S/PRST/1997/49, October 29, 1997, text can be accessed online at <http://www.un.org/Docs/sc/statements/1 997/prstg749.htm> (last visited 28 March 2002).

${ }^{13}$ See Christine Gray, "After the Ceasefire: Iraq, the Security Council and the Use of Force" (1994) 65 British Yearbook of International Law 135 at 154, 167 . 
content of the warning, the expression "severest consequences" is obviously an order of magnitude beyond "serious consequences." Combining form and substance, an external observer would be forgiven for interpreting there to have been a deeper level of collective resolve in 1998: if warnings of "serious consequences" outside the body of a Security Council resolution could be understood (that is, in the 1993 and 1997 precedents) as an implicit signal by the Security Council that force may be used, then "severest" consequences warned - or threatened - within a resolution must $a$ fortiori be an even clearer signal: an implicit authorization.

However, in 1998, matters had changed, it would seem. During the debate over the terms of Resolution 1154, China stated emphatically that the warning of "severest consequences" in that resolution would, in China's words, not lead to "automatic authorization of the use of force against Iraq." ${ }^{4}$ On the surface of things, it would seem that China knew full well what normative stakes were involved in Resolution 1154's terminology in light of the signalling games of 1993 and 1997, in which it, China, had participated. At this point, the role of soloist in the concerto, which had previously been that of the president, was now taken up by SecretaryGeneral Annan himself. His solo performance in the interpretive tug-of-war over what Resolution 1154 was permitting involved a United States television news appearance. Should Iraq not comply with the MOU he had brokered in early 1998, Annan was asked, would the use of military force require a new Security Council resolution or would Resolution 1154's language be sufficient to allow willing states to take military measures against Iraq? In what were obviously very closely constructed sentences, Annan noted that the United States had consulted broadly throughout the crisis, and this action had resulted in Annan going to Baghdad to seek the MOU. Then, he added the following: "The Russians, the French and Chinese ... resisted [the] idea of automaticity. And therefore, if the United States had to strike, I think some sort of consultations

${ }_{14}$ For the summary records of China's remarks, see UN Doc. S/PV.3858, 1998, at 14 . With respect to the fact that China was reported to have the support of two other permanent members, see John Goshko, "Three on Security Council Oppose 'Automatic Trigger' on Iraq," Washington Post, February 28, 1998, at A20: "Diplomatic sources said that France, Russia, China and council members belonging to the Non-Aligned Movement, all of which have opposed military strikes, are insisting that any resolution require further council consideration before force is authorized. The sources said these countries are agreeable to warning Iraq of potential consequences but, as of now, refuse to accede to the idea of an automatic trigger." 
with the other members would be required."15 Some eight months later, in November 1998, the United States, the United Kingdom, and France eventually did decide to use military force on the basis that Iraq had continued to fail to comply with both Resolution 687 and the March 1998 MOU.

For the purposes of the present discussion, what is significant (and needing of more study) is the extent to which these states engaged in consultations with other Security Council members before unleashing their bombing campaign in November 1998 . Recall China's own carefully chosen words in the debate over the language of Resolution 1154 - China had objected to an interpretation of the words "severest consequences" that would permit an automatic recourse to force - and Secretary-General Annan had glossed over that objection by seemingly suggesting that "consultations" would satisfy China's concerns with automaticity. To the extent that the United States, the United Kingdom, and France did consult prior to their strike in November 1998, did they do so in the belief that at some level China had sent a normative signal that it understood that force could result without a subsequent, fresh resolution by virtue of its own careful choice of words during the debates over Resolution 1154 and its subsequent lack of objection - or, at least, objection on the public record - to the Secretary-General's interpretive spin broadcast on US television, which was widely reported thereafter?

What, precisely, is the relevance of the foregoing narrative? At least four points can be made. First of all, as I hope has emerged with some clarity from the discussion itself, a Security Counciloriented practice of engaging in layered signalling games blurs with the creation of real-world, shared understandings on how to go about interpreting Security Council resolutions in which the implicit authorization of the use of force (for example, in Resolution 1 154) is at stake. Second, as a corollary to the first point, the handling of Iraq suggests how the frames of reference within which Security Council resolutions are drafted are constantly evolving. Another way of putting this point is to say that baseline understandings evolve in such a way that formulations that are initially viewed as being opaque by external viewers and as being coded by internal

${ }^{15}$ See "Annan: U.S. Must Consult before Attacking Iraq," remarks of the SecretaryGeneral, which can be accessed online at <http://www.cnn.com/WORLD/ 9803/o8/iraq.wrap/index.html> (last visited March 28, 2002) [emphasis added]. The remarks of the Secretary-General were made on ABC News, This Week (ABC television broadcast, March 8, 1998). 
participants come to take on a clarity. For example, the search for implicit authorization of the use of force can evolve from a broad contextual inquiry into a simple semantic exercise of identifying a key phrase that has been invested with particular meaning at some point in time. So, just as "all necessary means" (recall Resolution 678 ) is now an accepted code for Security Council authorization of military force and, as such, is virtually an "express" authorization within the language community in question, the practice of warning of "serious consequences" is perhaps becoming generally understood by the permanent members of the Security Council to be a warning - or, in line with the earlier discussion, a hybrid warning-threat - that future military action may occur without a subsequent Security Council resolution expressly authorizing this action. Measured against the conventions of drafting legal instruments, the lawyer concludes that, when the Security Council goes on to use the same language again, this use is intentional and interpreters are meant to understand the words in the new case as they have come to be understood in light of previous practice.

Third, Security Council resolutions are framed not only by the Council's own practice but also by the Charter itself and by all of the presumptions of interpretation that one can infer from it. For example, two American scholars in a recently co-authored article conclude that the interaction of the Charter's text and overarching policy considerations yield an interpretive rule that Security Council authorizations of force must be explicit (or, at the very least, clear) and not implicit. ${ }^{16}$ Jules Lobel and Michael Ratner start with two fundamental Charter values, the peaceful settlement of disputes and the principle that force is to be used "in the interest of and under the control of the international community." From these twin values, they argue that an overriding policy must be viewed as being part of Chapter VII, namely that the Security Council must retain "strict control" over the initiation, duration, and objectives of force. If the argument for this policy is indeed a sound one, then specific consequences follow with respect to interpreting the meaning of Security Council resolutions and, what amounts to the same thing, with respect to the language that the drafters of the Security Council resolution must use if they seek to secure certain results. Two such consequences, from Lobel and Ratner's perspective, are,

16 Jules Lobel and Michael Ratner, "Bypassing the Security Council: Ambiguous Authorizations to Use Force, Cease-Fires and the Iraqi Inspection Regime" (1999) 93 American Journal of International Law 124. 
again, that there is a requirement of explicit Security Council authorization of force and also that, in some grey zone between the explicit and the implicit, ambiguous aspects of authorization should be narrowly construed. ${ }^{17}$ The broader point that emerges is that there is a symbiotic link between the premises and conventions governing the interpretation of Security Council resolutions and the interpretation of the Charter itself. As such, what we may be witnessing with the various levels of collaboration in coded silences and half-hearted resistance is a simultaneous re-interpretation of the Charter's premises through a Security Council practice that has begun to condone, even embrace, the possibility of treating Security Council resolutions as containing implicit authorizations to use force.

The fourth and final point of relevance that emerges from the Iraq example is that it helps us understand why a focus on customary international law as a locus for new law on humanitarian intervention may make little sense. Given its special "constitutional" status, the Charter cannot be contradicted by customary international law, unless the customary norm is of that very special kind known as jus cogens. At most, custom can develop in a subject area covered by the Charter only in a way that complements the Charter or, conceivably, in a way that conflicts with some Charter values if the Charter can be reasonably understood as having created a permissive gap in the text within which custom is to be permitted to develop. ${ }^{18}$ The essential point is that the Charter and custom exist in the shadow of each other, each conditioning the other, such that references to the customary law on humanitarian intervention should be more self-consciously understood as being really about interpretive practice that is related to the Charter. ${ }^{19}$ It makes little

$17 \mathrm{Ibid}$. at 219 .

${ }^{18}$ It is this latter move that some scholars and states attempt to make when they argue that Article 51 of the Charter should be viewed as permissive and not preclusionary in terms of the circumstances that generate a right of self-defence. Article 51 states that self-defence is triggered if "an armed attack occurs." There are those who make the point that this language should not be read as if it says "if and only if an armed attack occurs." In this way, these jurists seek to find open space in the customary realm for the law of self-defence to develop as custom.

${ }^{19}$ While being at pains to emphasize custom exists apart from the Charter, the International Court of Justice could, nonetheless, be read as having said something similar in Military Activities in and against Nicaragua Case (Nicaragua v. United States of America), [1 986] I.C.J. Rep. 14 at para. 181 : "However, so far from having constituted a marked departure from a customary international law which still exists unmodified, the Charter gave expression in this field to principles 
sense conceptually to say that custom evolves separately from an interpretation of powers and duties within the Charter itself. Yet also, from a policy perspective, one must prefer evolutionary interpretations of a constitutional instrument to an approach that effectively creates a gap in the applicability of the constitution precisely in the fields in which one would expect it to apply with full force. Thus, humanitarian intervention is best seen either as something condemned to be morality's rebuke to legality in situations where necessary action is not forthcoming because of Security Council reticence or internal blockage or, instead, as a practice in quest of lawfulness through the complex interpretive interaction of words and conduct with the Charter text - not as something that exists in a Charter-separate "customary" world. Given that it is extremely unlikely that a formal Charter amendment can occur any time soon, the pressure to embrace intervention interpretively as part of an evolution of the meaning of the Charter itself is understandably great. The burden of my account of some of the interpretive controversies concerning the Iraq situation and the discussion of the normative significance of those narratives has been to demonstrate that there is good evidence that the interpretive re-fashioning of the Charter's law on peace and security is being pursued with some vigour by key actors, who are not only states such as the United States and the United Kingdom but also a particularly charismatic and influential Secretary-General.

\section{UN Charter and Evolutions in Meaning}

It is by now trite law that evolutionary meanings are possible both as a matter of general international treaty law and also as an accepted way of viewing the capacity of the UN Charter to have prevailing meanings revised in light of some form of moving consensus. Let us speak of "interpretive evolutions" as the general category for meanings that evolve either simply by clarification (where there is an initial period in which ambiguity produces disagreement and, thus, no consensus meaning, but where consensus on meaning eventually clarifies) or by a radical re-reading of the text.

already present in customary international law, and that law has in the subsequent four decades developed under the influence of the Charter, to such an extent that a number of rules contained in the Charter have acquired a status independent of it. The essential consideration is that both the Charter and the customary international law flow from a common fundamental principle outlawing the use of force in international relations." 
By way of contrast, let us use the term "legislative interpretations" to refer to interpretive evolutions in meaning that are closer to the latter end of the spectrum - that is, interpretations in which there is an element of re-writing the text under the formal guise of rereading it (either by implying rules and principles into the text or by consciously reading words in a way that accords neither with their ordinary meaning nor with what is commonly understood to have been their original meaning at the time of adoption of the text).

However radical an interpretive evolution in meaning may be, the key point is that the evolution is inextricably connected to the practice of argument in which text is brought to bear on concrete situations in such a way that, with time, certain interpretive arguments prevail. An oft-given example of interpretive evolution arising through argumentative practice in the Charter context is that of Article $27(3){ }^{20}$ This provision sets out the voting requirements for a Security Council resolution to be adopted; such adoption is in turn necessary for the Security Council to bind states to its will. One of the conditions for a resolution to be adopted is that nine "affirmative" votes are needed and also that the "concurring" votes of all five permanent members are required. Two issues have arisen. First of all, can an abstention by a permanent member count as a "concurring vote"? Second and more radically, can the requirement of the "concurring votes of the permanent members" be satisfied when a permanent member is absent from the vote and, thus, casts no vote at all?

With respect to the abstention-as-concurring issue, interpretive controversy has been relatively mild. With some fits and starts, ambiguities in both the text and the negotiating record of Article 27 (3) were resolved through consistent practice beginning as early as $1946 .{ }^{21}$ Certainly, abstentions are now universally understood

20 "Decisions of the Security Council on all other [non-procedural] matters shall be made by an affirmative vote of nine members including concurring votes of the permanent members; provided that, in decisions under Chapter VI, and under paragraph 3 of Article 52, a party to a dispute shall abstain from voting." Article 27 (3) of the Charter, supra note 1.

${ }^{21}$ Lobel and Ratner, supra note 16 at 135 , note 42 . See also Constantin Stavropoulos, "The Practice of Voluntary Abstentions by Permanent Members of the Security Council under Article 27, Paragraph 3, of the Charter of the United Nations" (1967) 61 American Journal of International Law 737, notably at the article's final sentence at 752: "That practice [of voluntary abstentions counting as concurring votes] has been acquiesced in by other Members of the Organization, and can now be considered a firm part of the constitutional law of the United Nations." 
to count as concurring votes. Indeed, China has, throughout the 1990 , quite consistently practised a policy of abstaining in many contexts in which it is uncomfortable with the military interventionism being proposed by the Security Council. ${ }^{22}$ In this way, China's concur-but-do-not-affirm policy has permitted a form of consensus to develop that has permitted the Security Council to become exceptionally active in a number of crises during the 1990 .

With respect to the absence-as-concurring issue, one crisis - the Korean peninsula crisis of $195^{\circ}-$ has come to be taken as interpretively constitutive by many commentators and most, if not all, states. In protest of the recognition of the nationalist Taiwan-based regime, which was being treated as the government of China for purposes of representation in the United Nations, the Soviet Union had been boycotting the Council for some five months when North Korea invaded South Korea ${ }^{23}$ In the absence of the Soviet delegate, the Security Council adopted a series of four recommendatory resolutions that, in effect, counselled states to assist South Korea in its self-defence and, then, for such states wishing to give such assistance, to place their forces and equipment under the unified command of the United States. On one account, a large percentage of the members of the United Nations of the day (some 53 per cent) sent messages of support for the Security Council initiative. ${ }^{24}$ The Soviet Union's position was that these resolutions were ultra vires because of the Soviet Union's failure to concur due to its absence. This view was de facto overridden by the generality of support for the Council combined with the passage of time, such that this general interpretation took on a de jure life as the governing interpretation on the question of absence within Article 27(3). I say "the generality of support" because the mechanism by which this interpretation was validated should be viewed as one of a general, as opposed to universal, recognition of the interpretive evolution in question. In

22 "On April 4, 1946, Australia was the first non-permanent member, and on April 9, 1947, the United Kingdom was the first permanent member, not to take part in a vote of the Security Council. This practice, which has been followed by other permanent members of the Security Council, has been used most frequently by the People's Republic of China." Bruno Simma and Stefan Brunner, "Article 27," in Bruno Simma, ed., The Charter of the United Nations: A Commentary (New York: Oxford University Press, 1994) 433 at 453.

${ }^{23}$ Myres McDougal and Richard N. Gardner, "The Veto and the Charter: An Interpretation for Survival?" (1951) 6o Yale Law Journal $25^{8}$ at 259

${ }^{24}$ Ibid. 
contrast to the abstention-as-concurring issue, it would be obfuscation in the absence-as-concurring context to speak of the acquiescence of states as having been the validating mechanism without specifying that one key interested actor did not acquiesce. Thus, an interpretation evolved rather as customary norms evolve - with general and widespread support but without the need for all interested actors to be participating in the practice that produces the normative shift (even a key actor in the context, which in this case was a permanent member on an issue crucial to its special place in the UN system).

The Article 27 (3) example falls closer to the end of interpretive evolution (that is, the clarification of an ambiguity in the Charter text) than it does to the end of what I have called legislative interpretations. This fact partly accounts for how it is that with time the Soviet Union's lack of participation in the initial forging of the interpretation on the absence question has not generally been treated as being fatal to that interpretation. There is, however, another major example of interpretive evolution of the Charter that is significant for our discussion because it involves a clearly "legislative" interpretation - indeed, some would say it came very close to an interpretive amendment of the Charter or, less provocatively, to an interpretive modification - and it occurred in the face of vocal resistance from powerful states. The example in question is that of the re-interpretation of the meeting of Chapter XI of the UN Charter, which is entitled the Declaration Regarding NonSelf-Governing Territories.

This term - non-self-governing territories - is amongst the baldest of euphemisms in international legal history, in that it has served as a code for "colonies." The key point is precisely that Chapter XI of the Charter makes no express reference to colonization. ${ }^{25}$ Apart from the semantic avoidance of calling colonization for what it is, the text also contains no duty to de-colonize or any right of a "non-self-governing" people, as a collectivity, to take that course, including through independence if it wishes. Rather, the paternalistic and, indeed, racist notion of a sacred trust became the governing concept according to which the only duty expressly placed by the Charter on the administering power (the colonizer) was to attend to the well-being of the populace and to foster the

${ }^{25}$ Chapter XI consists of two articles, Articles 73 and 74 , neither of which use the word "colony" or any derivative. 
movement of the non-self-governing population towards a capacity for "self-government." 26

Yet, despite the hurdles of text and power, anti-colonial states (including "pre-states" such as India) and especially newly decolonized states began to use the UN General Assembly as the locus for a normative battle against colonization in which the right of peoples to self-determination was the battle standard. Despite the lack of receptivity in Chapter XI of the Charter to a duty to decolonize - and, indeed, a complete failure to even acknowledge that colonization existed - this coalition of states, with support from civil society, succeeded in having a high-normative resolution of the General Assembly passed that affirmed the right of all peoples to self-determination and listed the right of a people to organize itself into an independent state as one of the choices such a people could make whatever the will of the colonizing power. ${ }^{27}$ The 1960 Declaration on Granting Independence to Colonial Countries and Peoples (Colonial Declaration) was increasingly invoked as the authoritative interpretation of the meaning of Chapter XI of the Charter to the point that, in relatively short order, the right of colonized peoples to self-determination and the associated right to become independent were read into the Charter despite the lack of any express recognition of either concept in the text itself. ${ }^{28}$

${ }^{26}$ It is only with respect to a special kind of colony called the "trust territory," which, in effect, were / are colonies of losing powers in both the First and Second World Wars, that the Charter specifically refers to the independence of the peoples of trust territories as a goal, however much it is a hedged goal. The specific mention of independence with respect to this form of territory and its stark absence in relation to the broader category of Chapter XI non-self-governing territories reinforced the textual and background assumptions that the Charter did not intend that colonizing powers be under a duty to de-colonize. See Chapter XII, entitled "International Trusteeship System," Articles $75^{-85}$ and notably Article 76 , of the Charter, supra note 1.

27 Declaration on Granting Independence to Colonial Countries and Peoples, UN GA Res. $1514(\mathrm{XV})$, December 14, 1960 [colloquially known as the Colonial Declaration].

${ }^{28}$ See, for example, W. Ofuatey-Kodjoe, "Chapter Seven: Self-Determination," in Oscar Schachter and Christopher Joyner, eds., United Nations Legal Order, vol. 2 (New York: Cambridge University Press, 1995) 349 at 350: "Still others have argued that the principle of self-determination has evolved into a legal right by virtue of UN practice. For instance, considering the Declaration on the Granting of Independence to Colonial Countries and Peoples, Rosalyn Higgins arrived at the conclusion that 'that Declaration, taken together with seventeen years of evolving practice by the United Nations organs, provide ample evidence that there now exists a legal right of self-determination." 
Institutions evolved to push this normative understanding and to put colonizing states under a spotlight. Most notable was the Decolonization Committee, which was (and, indeed, continues to be) in charge of identifying those peoples who are to be considered nonself-governing and to oversee the process of decolonization, usually through a UN-supervised vote on political status. Thus, we see an example of a virtual constitutional amendment to the Charter in an area of high political salience and against the wishes of very powerful actors - a phenomenon that occurred by way of an interpretive strategy that harnessed the normative force of the General Assembly by way of its capacity to adopt special resolutions called declarations. An important element of the story is that the interaction between the General Assemby's initial and subsequent pronouncements on the decolonization question and the Charter text occurred in a context in which the Charter itself expressly states that, other than for certain matters internal to the workings of the UN, General Assembly resolutions are recommendatory only. That being the case, the way in which Chapter XI came to be rewritten highlights the sterility of thinking that embraces a rigid dichotomy between binding and non-binding legal effect and obscures the reality that legality operates as much in degrees as in an off/on fashion, especially in international relations.

The decolonization example further gives rise to the following important points. First of all, the initial resistance of colonizing states to some kind of duty to decolonize did not last all that long once the anti-colonial coalition had succeeded in having the Colonial Declaration adopted in the face of resistance from a clutch of states. As such, we can see that interpretive change need not be initiated with all parties onboard. Nor, however, can it be imposed by some interested parties without having eventually achieved some threshold of acquiescence on the part of those inclined to object to the legal development. In tandem with the notion of acquiescence, it is helpful to think in terms of some kind of requirement of sufficiently general recognition by the international community as a whole as a way to think about legal development occurring in a "legislative" fashion - that is, in a fashion that binds all members of the community.

In this respect, the interpretive change to the Charter's law on colonized peoples would seem to have similarities to the way we think about the evolution of customary norms. However, there may be important differences between the extent of acquiescence, 
or the comprehensiveness of general recognition, with respect to treaty texts compared with customary norms. Whatever the epistemological problems may be, we tend to view these texts as having a certain "objective" existence. We speak of their meaning being "in" that text in light of its purposes and context(s). Of course, we do realize that meaning is something generated by interpretive communities creating shared understandings. In that sense, we are not naive: texts do not generate their own meaning. So, by "objective," I mean the idea of something chronologically prior to the act of interpretation, something legislated through a legitimate process that requires us to imagine it - the text - as having its own integrity and, thus, standing apart from any given state's or societal sector's understanding of it.

All of this discussion suggests the potential for authoritative new interpretations that are not necessarily consensus ones and that, indeed, can be argued to be legally correct in the face of resistance by powerful actors - at least to the extent that other important actors share the same interests as the resisters and have begun to embrace the new legal development (against interest) in such a way that increases the confidence with which we can understand the legal development as reflecting the common interest. In domestic law we are used to interpretations through the courts as creating, through decision, meanings that are accepted as law even if incredibly powerful social and political interests have been resisting such an interpretation. There is no such court-like actor in the international system; the International Court of Justice certainly does not play a parallel role. However, the decolonization example suggests that political institutions, most notably the General Assembly, can play a very special role in interpretively rewriting texts even in the face of serious resistance.

\section{From Kosovo to the General Assembly}

Having set the scene with some discussion of the normative politics in the Security Council over Iraq and in the General Assembly over decolonization, we now turn to the Kosovo crisis. It is common ground that there was no explicit authorization for NATO's use of force against Yugoslavia in late March 1999. As well, no one would argue that there was any explicit retroactive endorsement of NATO's decision to go to war when the terms of the peace settlement with Yugoslavia were incorporated into Security Council Resolution 
$1244 .{ }^{29}$ Yet, the idea of implicit authorization in some kind of mutually supportive relationship with implicit retroactive validation has

29. The lack of explicit retroactive endorsement is in considerable contrast to the retroactive response by the Security Council to ECOWAS's 1990 intervention into Liberia. In that context, the Security Council did not go so far as to expressly say that what was an illegal intervention was to be treated as retroactively validated as lawful, but the language of "commend[ing]" the intervention was used. See UN Security Council Resoultion 788 (1992), November 19, 1992, text can be accessed online at <http://www.un.org/documents/sc/res/1992/ s92r788e.pdf $>$ (last visited March 28, 2002), in which, in operative paragraph 1, the Security Council "[c]ommends ECOWAS for its efforts to restore peace, security and stability in Liberia." In addition, in paragraph 4 , the Council uses more implicit, but still significant, language when it "[c]ondemn[ed] the continuing armed attacks against the peace-keeping forces of ECOWAS in Liberia" [emphasis added]. There is also an indirect form of "support and endorsement," albeit in the preamble only, when the Council welcomes the Organization of African Unity's "endorsement and support" of ECOWAS. By such a double reference to a pan-continental regional organization and a sub-regional organization, the Council may well have wanted to signal that the retroactive validation found in paragraph 1 (recall "commends ECOWAS ...") had something to do with the depth of legitimacy created by two regional organizations acting in concert, a signal even more strongly hinted at by another preambular paragraph "[r]ecalling the provisions of Chapter VIII [Regional Arrangements] of the Charter." As Resolution 788 occurred a full two years after the ECOWAS intervention, evidence of ongoing acquiescence by the Security Council during those two years would help bolster an interpretation that paragraph 1 of Resolution 788 amounts to a retroactive validation removing any unlawfulness that might have otherwise attached to the act of intervention. In this respect, the following observations by Christine Gray in "Chapter Six: Regional Arrangements and the United Nations Collective Security System," in Hazel Fox, ed., The Changing Constitution of the United Nations (London: British Institute of International and Comparative Law, 1997) 91 at 104-5, are of interest: "In this [Liberia/ ECOWAS] instance ... it is striking that not much attention was paid in the Security Council even to the question of the legality of the operation under the UN Charter. States in the Security Council debates simply assumed that ECOWAS had legally established peacekeeping forces. The ECOWAS communiqués to the Security Council made no express reference to Chapter VIII but Nigeria spoke of 'ECOMOG as holding the fort for the UN in accordance with Chapter VIII.' The USA and China spoke simply of the peacekeeping forces set up by ECOWAS and appeared to assume their legality."

Some commentators addressing the Kosovo intervention have considered Resolution 788 's treatment of the Liberia situation to be a precedent for the possibility of the Security Council sanctioning an intervention after the fact. See, for example, Christopher Greenwood, "International Law and the NATO Intervention in Kosovo" (2000) 49 International and Comparative Law Quarterly 926 at 929 . This point is fine as far as it goes - and indeed this is an important benchmark against which future Security Council resolutions do indeed need to be interpreted - but the simple fact of a post-intervention Security Council 
some support as the way that we might think about the possible lawfulness of the NATO action. However, those individuals making such an argument have an uphill battle. No single provision in any single Security Council resolution can be pointed to as the textual location for inferring either a prior authorization or an ex-post factovalidation. Rather, any lawfulness such as may exist can only be "located" in the Security Council texts taken as a whole and viewed over time, not as isolated snapshots.

Now, I would note that I adhere to a set of views about law, including (if not especially) international law, which understands both the identification of law and its articulation in concrete decisionmaking contexts in terms of a rhetorical enterprise. Rhetorical theories of law and justification emphasize that lawfulness need not be seen as an either/or matter and, even less, as one in which formal textual sources may be invoked to the exclusion of other relevant considerations that possess various degrees of normative weight in argument. Legal justification becomes a matter of the degree of persuasiveness of an overall argument, in which a multiplicity of interconnected individual arguments are composed into some harmonious whole and in which the cumulative persuasive force of the totality of arguments is assessed in terms of the aesthetics of the ensemble. Such an assessment includes both formal properties of coherence in argument and the receptivity of particular audiences to particular kinds of arguments or combinations thereof. From this standpoint, shared, or at least compatible, premises play a crucial role in linking diverse arguments and contributing to their combined force. ${ }^{30}$

resolution seeking to deal with the results of an intervention does not in itself amount to the support and endorsement of the intervention itself. Absent something explicit along the lines of what the Security Council said about the Liberia context, the Council must be taken only to be dealing with the aftermath of a war in the best fashion that it can, as it would deal with any war, however illegally initiated.

${ }^{30}$ The kind of premises to which I refer include understandings about the prima facie legal standards in play, about the facts, about the nature and function of the law, and of the particular decision-making institution called upon to act, about systemic background values that cocoon legal reasoning, about the balance between textual, contextual, and instrumental arguments in one's approach to interpretation, and so on. For an account of how political and moral discourses can insinuate themselves into the realm of legal rhetoric in the use of force context, see Craig Scott, "Grenada, Nicaragua and Panama: Tracking Force-for-Democracy Discourse in the 1980 ," in Yves LeBouthillier, Donald McRae, and Donat Pharand, eds., Selected Papers in International Law: Contribution 
What, then, have been the main arguments that some advocates of the lawfulness of the NATO intervention have put forward albeit with each advocate emphasizing specific arguments more than others and combining them in different ways? ${ }^{31}$ First of all, many start with the fact that the Security Council had indeed taken cognisance of the escalating humanitarian crisis in Kosovo and had adopted Chapter VII resolutions that made clear that Yugoslavia was under a legal duty to remedy the situation. Second, prior to March 1999, a strategy of threatening force had already been used by NATO. Most notably, the United States diplomatic envoy, Richard Holbrooke, had gone to Belgrade in the fall of 1998 in order to threaten Slobodan Milosevic with military force should he fail to agree to a cessation of violence in Kosovo. Milosevic did indeed agree to such cessation and also to the insertion of observers from the Organization for Security and Cooperation in Europe. Security Council Resolution 1203 of October 1998 did not condemn the threat of force that had produced this agreement but, rather, welcomed the agreement secured with the assistance of threats by "endorsing and supporting" the agreement. ${ }^{32}$ This

of the Canadian Council of International Law (The Hague, London, Boston: Kluwer Law International, 1999) 169 at $195-200$.

31 These have been distilled and amalgamated from, inter alia, the accounts in the following articles: Bruno Simma, "NATO, the UN and the Use of Force: Legal Aspects" (1999) 10 European Journal of International Law 1 ; Ian Brownlie and C.J. Apperley, "Kosovo Crisis Inquiry: Memorandum on the International Law Aspects" (2000) 49 International and Comparative Law Quarterly 878 and 910 ; Christine Chinkin, "The Legality of NATO's Action in the Former Republic of Yugoslavia (FRY) under International Law" (2000) 49 International and Comparative Law Quarterly 345; Greenwood, supra note 29; Vaughan Lowe, "International Legal Issues Arising in the Kosovo Crisis" (2000) 49 International and Comparative Law Quarterly 358; Ruth Wedgwood, "NATO's Campaign in Yugoslavia" (1999) 93 American Journal of International Law 828; Louis Henkin, "Kosovo and the Law of "Humanitarian Intervention" (1999) 93 American Journal of International Law 389; Richard Falk, "Kosovo, World Order, and the Future of International Law" (1999) 93 American Journal of International Law 41 2; and Michael Reisman, "Kosovo's Antimonies" (1999) 93 American Journal of International Law 425; Foreign Affairs Committee, House of Commons, United Kingdom, Fourth Report of the House of Commons Foreign Affairs Committee (June 7, 2000), Doc. HC28-I, text can be accessed online at <http://www.fas.org/man/dod-101/ops/2000/2802/index.html> (last visited March 28, 2002).

${ }^{32}$ UN Security Council Resolution 1203 (1998), October 24, 1998 at para. 1, text can be accessed online at <http://www.un.org/Docs/scres/1998/sres 1203 . htm> (last visited March 28, 2002): "Endorses and supports the agreements 
technique was, of course, was the exact formulation used in 1991 with respect to actual, as opposed to threatened, military intrusion into Liberia by ECOWAS. So, while it remains common ground that the Security Council did not repeat this formulation once NATO had actually intervened and Yugoslavia had then surrendered in the summer of 1999, the Security Council had indeed been willing to adopt a resolution in the fall of 1998 that stood for some kind of acceptance that threats of force may well be tolerated at a certain level by an enthusiastic embrace of results that appear to have only been achievable through such threats. This fact alone suggests a significant potential legislative reinterpretation of the Charter, given that Article 2(4) prohibits, on its face, threats of force and not only the use of force. ${ }^{33}$

Third, as the NATO action against Yugoslavia was underway, Russia tabled a motion before the Security Council that sought to have the NATO states condemned for an illegal initiation of a war. It appears that Russia may have radically miscalculated because that motion was voted down twelve to three. Only China and Namibia joined Russia in voting for its motion. While it is a completely disingenuous argument (that some, especially the United States, have nonetheless attempted) to suggest that this vote alone amounted to a validation of NATO's action, it remains the case that, from a perspective where normativity is a matter of weight, the view of the large majority of the Security Council was not without

signed in Belgrade on October 16, 1998 between the Federal Republic of Yugoslavia and the Organization for Security and Cooperation in Europe, and on October 15, 1998 between the Federal Republic of Yugoslavia and NATO, concerning the verification of compliance by the Federal Republic of Yugoslavia and all others concerned in Kosovo with the requirements of its resolution 1199 (1998), and demands the full and prompt implementation of these agreements by the Federal Republic of Yugoslavia."

${ }^{33}$ All of that said, Resolution 1203 does not expressly refer to the means adopted to achieve the agreement with Yugoslavia, so there is still some room to say that the Security Council simply did not address the question of the unlawfulness of any actions by the North Atlantic Treaty Organization [hereinafter NATO] in the lead-up to that October 1998 agreement. As well, some might be inclined to say that the loosening of tolerance for the rule against threatening force in international relations - assuming Resolution 1203 is an example of that loosening - does not in and of itself mean that the same agreement produced as a result of the actual use of force in the same circumstances would have been welcomed in the same fashion. However much diplomats wish for threats of force to be understood as credible threats, there is a qualitative difference between threatening and actually carrying out military action. 
significance in the overall calculus of whether there were sufficient reasons to adjudge NATO to have acted lawfully. ${ }^{34}$

Fourth, Secretary-General Kofi Annan once again stepped up to play an important discursive role. On at least one occasion, he as much as said that his view was that the Charter must be sufficiently flexible to allow for the properly motivated uses of force in certain humanitarian crises. In Annan's words, "[i]t is indeed tragic that diplomacy has failed, but there are times when the use of force may be legitimate in the pursuit of peace." 35 While Annan has not exactly been a reticent figure in making public pronouncements on various matters during his tenure as Secretary-General (recall the Iraq example), it is decidedly the case that, when he does, the terms of his public comments are very carefully chosen and formulated. This fact makes the preceding quotation all the more important to take seriously and to parse.

Fifth, the existence of UN Charter Article 53 on regional enforcement may have some relevance in the overall structure of argument. What Article 53 makes clear is that regional organizations are specifically contemplated as a legitimate agency of the United

34 It is important to note here that NATO states may have thought that they had Russia's quasi-consent to use force. Tim Judah in his book Kosovo, War and Revenge (New Haven: Yale University Press, 2000) $183-85$, describes how the foreign minister of Russia, Igor Ivanov, had said at a meeting with NATO foreign ministers that Russia would veto any resolution brought to the Security Council seeking permission to use force (that is, of the "all necessary means" kind), but that, if the Security Council was avoided entirely, all that Russia would do would be to "make a lot of noise" through a public protest. NATO's legal strategy may have assumed that Russia would not bring the matter to a vote in the way that it actually did and, thus, that there would be no voting record of $\mathrm{P}_{-5}$ opposition. This is all to say that, even as the failed motion by Russia indicates that a majority of the Security Council were opposed to the condemnation of NATO, it simultaneously is an important official record that the intervention did not have the support of two permanent members, China and Russia. It should also be noted in passing that there are several reasons why it was unacceptable for the NATO states to have invested so much meaning - that is, if they sincerely did - in the statements made by Foreign Minister Ivanov on that one occasion; however, elaboration of this point will have to wait until another occasion. See also the discussion in note 40 in this article.

${ }^{35}$ In Judith Miller, "Conflict in the Balkans: The U.N.; The Secretary General Offers Implicit Endorsement of Raids," New York Times, March 25, 1999, at A1 3 , Secretary-General Anan is quoted as saying: "I deeply regret that, in spite of all the efforts made by the international community, the Yugoslav authorities have persisted in their rejection of a political settlement, which would have halted the bloodshed in Kosovo and secured an equitable peace for the population there. It is indeed tragic that diplomacy has failed, but there are times when the use of force may be legitimate in the pursuit of peace." 
Nations for using force in collective security contexts. ${ }^{36}$ Of course, the fact that regional organizations may use force does not mean that they may use force based on their own appreciation of the situation and judgment. As a textual matter, Article 53 is clear that any regional enforcement action requires authorization of the Security Council, unless of course it involves not collective security as such but, rather, an act of collective self-defence. All of that said, however, the presence of Article 53 may suggest that the consensus necessary to produce regional enforcement of the kind carried out by NATO in the Yugoslavia context may be an area where implicit authorization is more justifiable, such that Security Council resolutions may be construed more flexibly in this context than, for example, if it is a situation of a single hegemonic state (with an ally or two) intervening on its own into another country. ${ }^{37}$

Sixth and finally, the Security Council resolution that inserted KFOR forces into Kosovo after the brokering of the peace agreement with Yugoslavia did not aver to the means by which peace came about, and the aforementioned "support and endorsement" that had occurred with respect to the temporary cease-fire agreement in the fall of 1998 was not repeated..$^{38}$ Nonetheless, some

${ }^{36}$ Article 53 reads in part: "The Security Council shall, where appropriate, utilize such regional arrangements or agencies for enforcement action under its authority. But no enforcement action shall be taken under regional arrangements or by regional agencies without the authorization of the Security Council." Here, it must of course be noticed that NATO has consistently resisted characterizing itself as a regional organization precisely in order to avoid an overly onerous degree of accountability to the United Nations. To the extent that this is formally the case even if, in substance, NATO is indeed a regional organization, the remaining points to be made with respect to Article 53 should probably be approached more in terms of a close analogy than in terms of a directly applicable argument.

37 Recall the linkage of the ECOWAS/Liberia precedent to regional enforcement, which is dicussed in note 29 in this article. This loosening of the standard for the interpretive importing of authorization into a Security Council resolution, of course, makes most sense where the intervention at issue is into a member state of the regional organization. This was not the case with respect to the NATO intervention, as Yugoslavia was out of area with respect to NATO's membership. Note also the Cuban missile crisis and the arguments relating to implicit authorization used by the United States, which were widely accepted in the Western Hemisphere at that time. See Abram Chayes, The Cuban Missile Crisis: International Crises and the Role of Law (Oxford: Oxford University Press, 1974); Roger K. Smith, "The Legality of Coercive Arms Control" (1994) 19 Yale Journal of International Law 455 at $491-93$.

${ }^{38}$ Security Council Resolution 1244 (1999), June 10, 1999, text can be accessed online at <http://www.un.org/Docs/scres/1999/99sc $244 . \mathrm{htm}>$ (last visited March 28, 2002). 
would contend that the failure to expressly condemn the means used in March 1999 and onward amounts to a form of Security Council acquiescence. As the argument might go, an endorsement of an outcome produced through the use of force triggers a responsibility to expressly condemn the use of force leading to that outcome or to have it understood that the use of force has been accepted. For many obvious reasons, this is a particularly weak argument from a rule-of-law perspective. It amounts to saying that those engaging in unlawful military activity can validate their own behaviour if they happen to be permanent members of the Security Council, by blocking any attempt to have that behaviour condemned when the Security Council attempts to deal with the aftermath of their military incursions. The perversions of this line of reasoning hardly need to be elaborated other than to note that, within the current framework of the Security Council, the failure to achieve the explicit "support and endorsement" of China and Russia is of greater significance for the (un) lawfulness of NATO's action than is the failure of the United States, the United Kingdom, and France to condemn their own actions through the Security Council. It should also be noted that this is a particularly weak form of argument in light of the ECOWAS/Liberia precedent. In that case, an actual military incursion had occurred, and the Security Council did use language particularly conducive to validating the incursion and not simply the state of affairs produced by it. So, while the ECOWAS intervention suggests that retroactive validation of some kind does fall within the jurisdictional purview of the Security Council, it undermines, at the same time, the case that any such validation took place in the Kosovo context.

I have already indicated that I am sympathetic to a theory of legal analysis that permits more flexible argumentation than is allowed by a traditional legalistic point of view. However, it is not as if anything goes. The phrase, "it is a matter of interpretation," cannot become shorthand for saying that any interpretation is valid as long as it is put forward with a straight face. Acknowledging that the legal enterprise is more complex than is accepted by many conventional approaches does indeed open up serious dangers - notably that, in a decentralized world order (especially one with a single hyper-power), the powerful may simply come to expect that their assertions carry with them the kernel of their only legality. The emphasis in rhetorical theory on the persuasiveness of an overall argument based on the arrangement of interacting and cumulative reasons cannot be allowed to generate into a crude listing of 
supporting reasons in the place of sophisticated argumentation, or even a listing of reasons accompanied by some attempt to invoke a quantitative metaphor according to which it is argued that, on balance, the arguments in favour (of legality or illegality) outweigh the arguments against. There must be a web of coherence that, in ideal terms, is persuasive to reasonable observers. And where no arm's-length reasonable observers have a determinative role in pronouncing upon legality, the degree of support for a position from the significant majority of interested actors - and especially from those actors that the legal system has already designated as having a special importance, notably the permanent five members of the Security Council - must be viewed as an important surrogate in terms of identifying which interpretive community must accept an overall argument as being persuasive for this argument also to be recognized as legally valid. A justificatory narrative cannot simply dismiss such factors as what the text appears to say or what counter-interpretations are advanced by non-supportive states. Rather than being seen as an on/off switch, legal authority is indeed best approached as a matter of degree, where neither received understandings of texts' meanings, on the one hand, nor a lack of wide consensus, on the other hand, are absolutely dispositive, but where both are still essential factors that have to be accounted for in such a way that a compelling case is made as to why they do not, ultimately, govern the result. For example, the text must at least continue to mean that implicit authorizations based on holistic readings of Security Council resolutions in their discursive context cannot be lightly presumed and that the community at large must at least be persuaded that, as Richard Falk has put it, "diplomatic alternatives to war have ... been fully explored in a sincere and convincing manner." 39 In Kosovo, many states - including many states looking at the matter in good faith - - are not convinced that this was the case. ${ }^{40}$

${ }^{39}$ Falk, supra note 31 at 856 .

${ }^{40}$ Here I would draw attention to the significance of one point made by Axworthy in his April 2001 Tokyo speech, supra note 3, when he revealed that Canada, during the Kosovo crisis, considered various different ways of trying to engage Russia so as to try to secure Russian agreement on a different resolution from one that would simply have authorized NATO states to use "all necessary means" based on NATO's judgment of necessity. Mention was made of the possibility that an economic for um such as the G-8 might have been an avenue to explore, had the right conditions been in place for such an initiative. In this regard, I would note that it does not take great imagination to conclude that Russia may 
However, for present purposes, I will leave one counterfactual (that of whether or not Russia could have been successfully engaged) in order to turn to another counterfactual, namely whether we would now be faced with a different interpretive terrain if NATO had gone to the General Assembly in order to attempt to secure a Uniting for Peace Resolution. ${ }^{41}$ The best consideration of this issue is probably found in the detailed report of the United Kingdom Parliament's Foreign Affairs Committee. ${ }^{42}$ In this report, it is stated that the Foreign and Commonwealth Office (FCO) of the United Kingdom had done a sounding and felt that they would not have been able to get the two-thirds majority needed for the adoption of a Uniting for Peace Resolution. As I will soon refer to the Uniting for Peace Resolution as part of the way forward, it is important at this juncture to understand that I am not assuming that the General Assembly has authority by virtue of the Uniting for Peace Resolution to authorize a military intervention that is not otherwise lawful on a legal basis, such as the right of self-defence or the consent of the relevant state parties. ${ }^{43}$ However, I am assuming that the

well have accepted that some intervention could be justified if it was centred on providing significant military support to the on-site Organization for Security and Cooperation in Europe observers on the ground in Kosovo as a result of the Fall 1998 agreement between NATO and Slobodan Milosevic. If Russia also had been content with some arrangement that would have involved itself in the military contingents, it is not at all unlikely that China would have followed its consistent practice of abstaining. In this way, a very different resolution might have gone forward in the Security Council as compared to the sort that Russian Foreign Minister Ivanov warned would be vetoed by Russia if brought before the council - in other words, a resolution that would indeed have authorized the use of force against Yugoslavia's will but in a way far different from the full-blown air campaign that NATO opted for. I have strong views on the failure to have fully pursued what might be called "the Russia option," but, as with the earlier footnoted discussion of the significance of Ivanov's role, elaboration of these views will need to be put aside for another occasion; see discussion in note 34 in this article.

${ }^{41}$ Uniting for Peace Resolution, UN GA Res/337A, UNGAOR, $5^{\text {th }}$ Sess., Supp. No. 20, at 1o, UN Doc. A/ $1775,1951$.

${ }^{42}$ Foreign Affairs Committee, supra note 31.

${ }^{43}$ Note that, because the Uniting for Peace Resolution foresees only a recommendation of action by the General Assembly, consistent with its powers under Article 10 of the Charter, it is misleading to say the General Assembly authorizes the intervention itself; rather, what it authorizes to binding legal effect are the expenses associated with a military operation that it has recommended come into being. In terms of the observation, this "authorization" is limited to interventions that would otherwise be lawful if states organized themselves outside the auspices of the United Nations. The International Court of Justice in Certain 


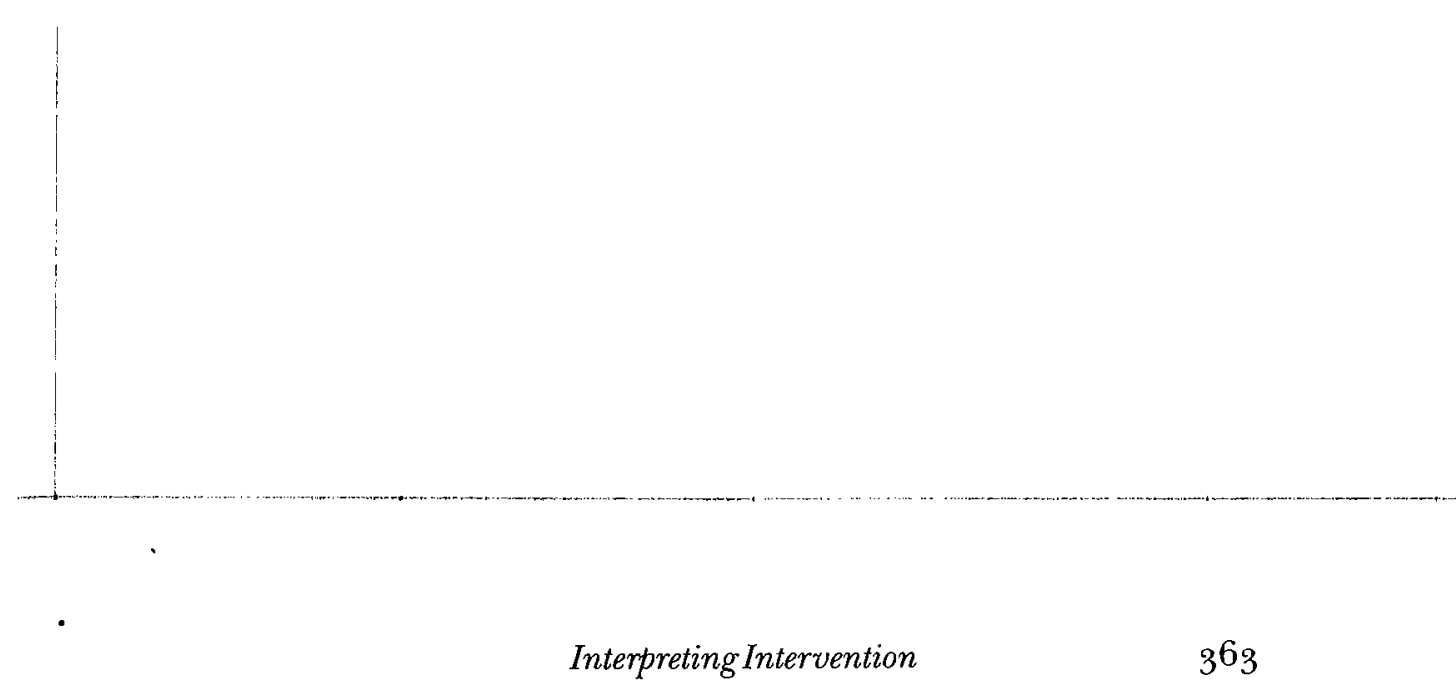

General Assembly may recommend enforcement action going beyond self-defence or invitation situations even if it could not go on to authorize expenses to support such action (were states to act on the recommendation). ${ }^{44}$ Only if other bases for intervention evolve,

Expenses of the United Nations, [1962] I.C.J. Rep. $15^{1}$ (Advisory Opinion) determined that financial levies on UN members to cover UN expenses arising from two peacekeeping operations (one in the Congo and one in the Middle East) were within the General Assembly jurisdiction. However, these missions were within the purview of states to have organized on their own due to the consent of the relevant actors. Similarly, once the Soviet Union returned to the Security Council and began to veto further Council resolutions on the Korean conflict, the General Assembly called on states to aid the UN Supreme Command, but, in this case, the title for intervention was one that states, again, could have invoked without UN authorization, namely, collective self-defence. (It was the Korean conflict that led both to the adoption of the Uniting for Peace Resolution and its first invocation.) This is all to say that, quite apart from the binding force of any Uniting for Peace initiative, the General Assembly has never, to the knowledge of this writer, purported to use the resolution as a way to authorize or order what the Charter assigns as the Security Council's function: enforcement action that cannot be justified by either self-defence or invitation.

${ }^{44}$ Kay Hailbronner and Ekhart Klein, "Article 10," in Bruno Simma, ed., The Charter of the United Nations: A Commentary (Oxford: Oxford, University Press, 1994) 227 , share this view:

From [the reasoning of the ICJ in Certain Expenses of the United Nations] ... it remains unclear whether recommendations of the GA can also include the adoption of enforcement measures. Consideration of the fundamental division of functions between the $\mathrm{SC}$ and the GA, and also the practice of the organization, support the interpretation that the authority of the GA is only limited ... when the GA is of the opinion that binding enforcement measures according to Chapter VII of the Charter, for which the SC alone is responsible, are to be decided upon.

There is a decisive difference between the recommendation of enforcement actions, and the actual taking of such measures. This is illustrated by the formal definition of the term "enforcement," according to which the existence of an "enforcement action" is not determined by the character of the action itself but by the binding nature of the measure taken. Therefore a non-binding recommendation is not to be considered "action," so that the GA is not prevented ... from recommending coercive measures. This norm only recalls the fact that the GA shall not take any enforcement measures binding on all member states (at 233).

Such valid recommendations of "coercive measures" would function in effect as recommendations to the Security Council because states would not be able to invoke General Assembly authority as a ground of lawfulness should they act on the General Assembly's recommendation. To the extent that the General Assembly recommends intervention to states outside the self-defence and consent bases for intervention, then it is recommending unlawful conduct. Any subsequent levies to pay for UN expenses related to unlawful uses of force would have to be seen as ultra vires the General Assembly. 
which do not require Security Council approval (for example, a freestanding power of humanitarian intervention), could the General Assembly piggyback on that lawfulness to both recommend such action and to go on to authorize expenses to support a UN operation that would result from states acting on the recommendation.

So, what is the significance of going to the General Assembly if the starting point is that the Security Council currently retains the only legal power to authorize humanitarian intervention and if Uniting for Peace Resolutions of the General Assembly are, in formal terms, simply recommendations? The starting point must be open acknowledgment that it is a form of interpretive amendment of the Charter that is at stake in seeking to make it lawful for states to intervene in other countries for humanitarian reasons, in limited circumstances, and without express Security Council authorization. As such, the General Assembly is surely as important a forum as any in terms of helping to nudge along a new authoritative consensus about what its governing text - the Charter should mean. This, after all, was exactly the role that the General Assembly played with respect to the previously described interpretive amendments to the Charter with respect to decolonization, to which I will return again shortly.

Hence, putting aside the question of the degree of bindingness of General Assembly resolutions, the central issue is one of finding implicit Security Council authorization by seeking far wider and representative consensus through General Assembly pronouncements than occurs when all of the interpretive analysis focuses on the words and conduct of fifteen Security Council members - and, most notably, the five permanent members - that take place as some kind of shadow dance with the UN Secretary-General and whomever, and whichever state, happens to be the president of the Council. With respect to the question of the degree of legal force attached to the envisaged General Assembly pronouncements, bindingness is not the pivotal question in a more open-ended framework in which what matters is the cumulative persuasiveness of multiple arguments. The normative value of a specific argument must be appreciated differently where any given argument is not being relied upon as the single and sole source of legal validity. In this respect, it is telling, if only in terms of the language used, that the FCO official testifying to the United Kingdom's Parliamentary Foreign Affairs Committee did acknowledge that "a resolution of the General Assembly would have been particularly persuasive [even though] the U.N. Charter still specified that military action required 


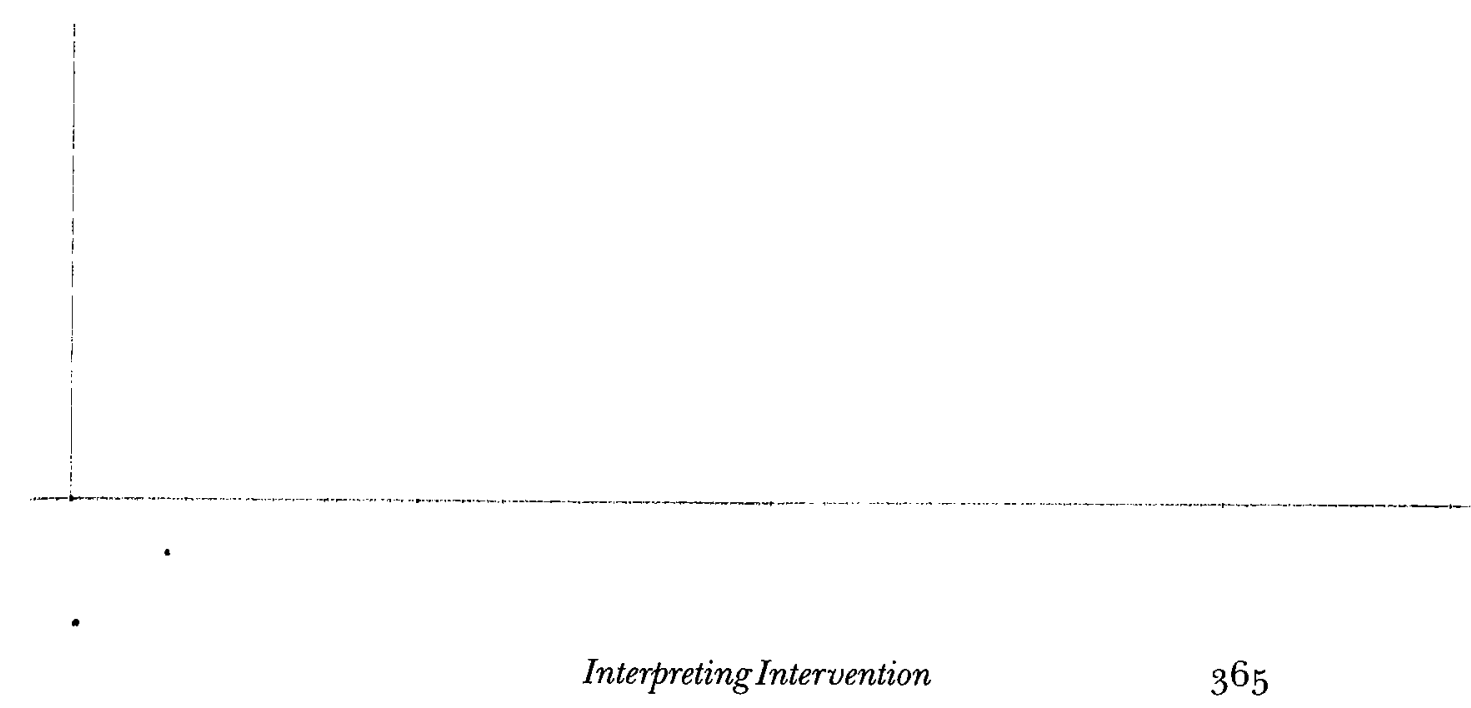

Security Council endorsement." 45 That said, it also bears remarking that the same FCO official went on to tell the committee that the voting pattern of fifteen Security Council members may have been more significant than a two-thirds General Assembly vote would have been. He said: "[But] in some ways a bare two-thirds majority would have been less persuasive than the majority (of twelve to three) actually secured in the Security Council on 26 March 1999," when Russia unsuccessfully proposed a resolution condemning the start of the NATO bombing. ${ }^{46}$

The contrast drawn by the FCO official warrants further comment. It reveals just how problematic is any conclusion that we can interpret the Security Council to have implicitly authorized or endorsed NATO intervention in the Kosovo context. Was the FCO official engaging in a crude quantitative comparison and concluding that the defeat of the Russia motion by 8 o per cent in a vote of fifteen states was normatively more significant than a vote of 67 per cent of approximately 190 states would have been? Keep in mind that the issue in this case is one that goes to the heart of a structural reinterpretation of the central constitutional text of the global legal order. It also points to a broader issue of legitimacy in the evolving process of reinterpreting the Charter. In this regard, I return now to the example of the 1960 Colonial Declaration.

The resistance of colonial states and their allies to this declaration did not stop those states who were wishing for the abolition of the inhumanity of colonialism from adopting the resolution by a significant majority. It then became the normative magnet around which a deeper and broader consensus first emerged, then discursively marginalized the remaining western colonial powers, and eventually produced the earlier-described reinterpretation of Chapter XI of the Charter. My argument is that a process of this nature is far more legitimate - and ultimately more effective in terms of taking root in the general consciousness - than a strategy that remains content with the ad hoc, less-than-transparent signalling game that is represented by the Iraq and Kosovo examples. Lloyd Axworthy in his Tokyo speech referred to the emergence of a sophisticated and passionate transnational civil society capable of allying with progressive state positions and shaming states as a

45. Foreign Affairs Committee, supra note 31 at para. 128 [emphasis added].

${ }^{46} \mathrm{Ibid}$. It is, of course, not surprising, given the United Kingdom's position in the Kosovo crisis, that this Foreign and Commonwealth Office official would have taken this position. 
whole into doing the right thing, such as on the land mines issue. ${ }^{47}$ Can such a "new power bloc," as referred to by Axworthy, be marshalled to help achieve a declaration on legitimate humanitarian intervention, which would draw inspiration from the Colonial Declaration?

It has not been my purpose to arrive at a point where I would suggest what the substantive content of such a resolution should be. However, consistently (I hope) with the general positions that I have advanced to this point, my tentative view is that such a humanitarian intervention declaration is best directed towards the Security Council or, viewed from a different perspective, towards the states who happen to be the members of the Security Council at a given time. The declaration would not be framed as a set of criteria for unilateral intervention - that is, intervention that cannot be justified by reference to a Security Council mandate. That is to say, the principles that would be stated in such a declaration should be framed in such a way that the declaration serves as the basis for the collective consideration of when and how intervention should occur with Security Council backing. The substantive criteria, the decision-making processes, and any institutional innovations that would be "recommended" to the Security Council by the General Assembly in the envisaged standing resolution would be designed to shine a global spotlight on Security Council politics so as to mobilize the power of shame on a timely basis and create something resembling a much more transparent process than currently exists.

By constructing the General Assembly declaration as a recommendation with respect to an international duty to intervene, we would simultaneously be constructing a framework that the General Assembly could draw upon in specific crises to assess whether or not the Security Council had acted reasonably with respect to any given crisis in terms of either failing to authorize intervention when needed or, conversely, failing to "fully explore" diplomatic alternatives "in a sincere and convincing manner" (to invoke again Richard Falk's language on the last-resort principle) or authorizing the wrong kind of intervention. In those instances when the General Assembly can achieve a significant majority in favour either of an express call for intervention or an express view that humanitarian intervention is not justified by the facts at hand, such an express statement can then become an interpretive baseline against which one interprets Security Council resolutions that do not contain

\footnotetext{
${ }^{47}$ Axworthy, supra note 3.
} 


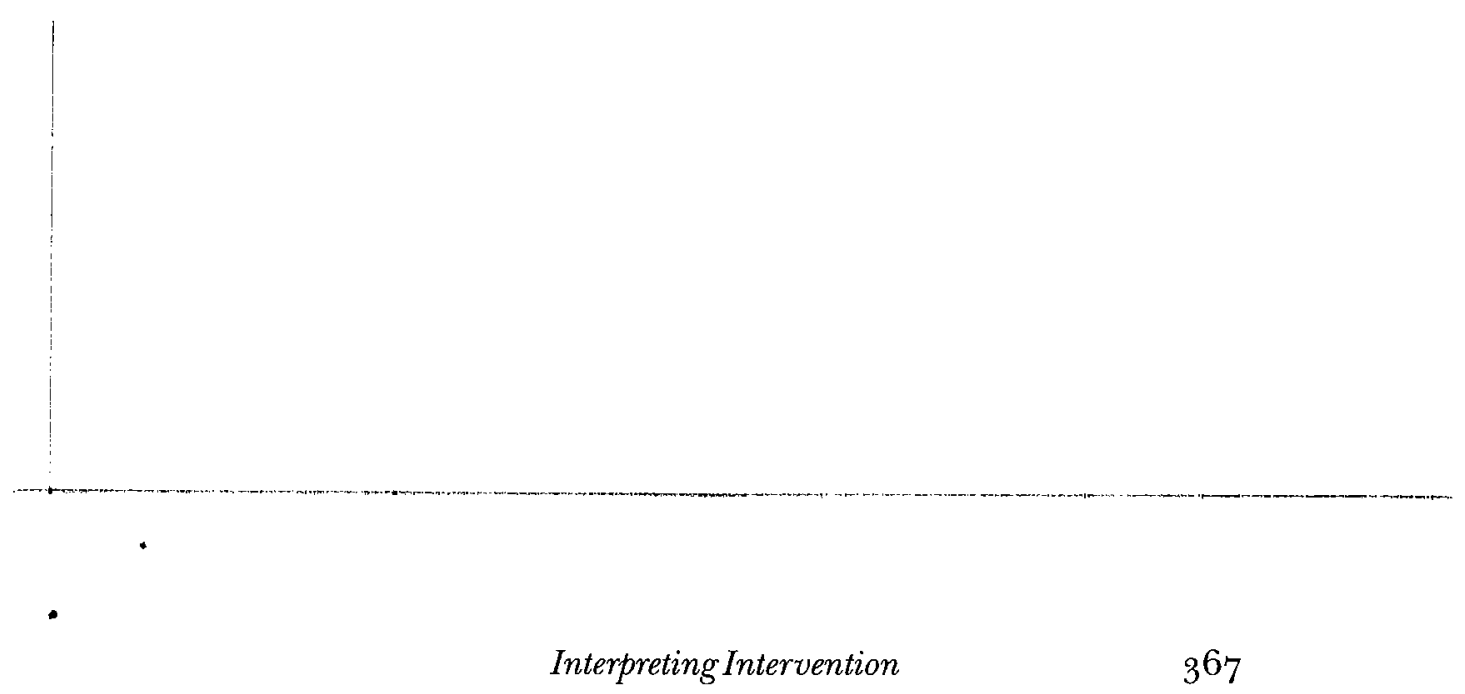

express authorizations or clear retroactive validations. In terms of a crisis-by-crisis role of the General Assembly, I am envisaging a normative document that would resemble the Colonial Declaration in terms of its statements of general principle but also have an operational element that would resemble an updated Uniting for Peace Resolution. Let us call the resolution the Declaration on Interventions for Human Security (DIHS). The DIHS could create a streamlined process involving a special committee of the General Assembly that meets in informal session to parallel all Security Council activity dealing with humanitarian crises that are on an alert list drawn up by the committee, so as to be prepared to pass judgment should the Security Council fail to act in accordance with the criteria set out in the overarching substantive principles of the DIHS. ${ }^{48}$

I have no illusions about the fact that many will react to this concrete proposal by dismissing it as not just abstract but also naive. All that I can say at this stage is that international politics have had a way of embracing so-called naivety in recent years - whether we are talking about the Convention on the Prohibition of the Use, Stockpiling, Production and Transfer of Anti-Personnel Mines and on Their Destruction ${ }^{49}$ or about the successful adoption of the Statute of the International Criminal Court, ${ }^{50}$ or about the successful targeting and delaying of the adoption of a multilateral agreement on investment as a result of a concentrated civil society campaign, or about the flourishing attempt to reset the global economic agenda through street protest. I do not envisage that such a declaration, as in the hypothetical DIHS, would be one that most, if any, of the permanent five members of the Security Council would support.

${ }^{48}$ It would be evident to scholars of UN law that such a declaration would probably also need to reorient the balance of powers between the General Assembly and the Security Council beyond that endorsed in the Certain Expenses of the United Nations judgment of the ICJ, supra note 43 , to the relatively limited extent of allowing the General Assembly to consider crises that are under active consideration by the Security Council while they are under such consideration. This is why I have taken care to indicate that the General Assembly would be in an informalsession.

49 Convention on the Prohibition of the Use, Stockpiling, Production and Transfer of Anti-Personnel Mines and on Their Destruction, September 18, 1997, Conference on Disarmament $C D / 1478$, text can be accessed online at $<w w w$.mines. gc.ca/VII_AA_I-en.asp> (date accessed: September 2, 2002).

${ }^{50}$ Statute of the International Criminal Court, July 17,1998 , UN Doc. A/Conf. $183 / 9$, text can be accessed online at <www.un.org/law/icc/statute/romefra. htm> (date accessed: September 2, 2002). 
However, it is possible that a creative combination of humanitarianism and multilateralism could build a momentum that would eventually pressure the major players to reconcile themselves with this process.

Very savvy organizing would undoubtedly be needed to build state coalitions and alliances with key actors in civil society. For example, it seems to me that the early and central involvement of the Organization of African Unity in a DIHS initiative would be crucial given that Africa is the continent that currently hosts the widest and most serious range of humanitarian crises and that has seen a host of failures of the international community to intervene, either preventively or reactively. My own - highly anecdotally informed - sense is that there tends to be, in Africa, a sophisticated approach to the question of the balance between concerns of imperialism and imperatives of humanitarianism in light of the Rwanda experience and ongoing horrors such as the multi-state war in central Africa. While very few people are starry-eyed about the dangers of an intervention model, at the same time there does seem to be widespread resentment in many African countries over Western indifference (if not callousness and racism), which is reflected by Western unwillingness to save African lives, especially after the Somalia syndrome had passed on its contagion to those who ended up handling the looming Rwanda genocide in the corridors of the United Nations and the capitols of powerful states. Finally, we might consider how China might be engaged in the initiative by elevating its policy of abstention throughout the 1990 s as a model to be emulated by other members of the Security Council in situations where a large majority of Council members representing a significant cross-section of states are in favour of a particular resolution.

\section{Sommaire}

Intervention et interprétation

L'auteur considère le bien-fondé de justifications pour l'intervention humanitaire faute d'autorisation expresse du Conseil de sécurité. Partant de l'affirmation par l'ancien ministre des affaires étrangères, Lloyd Axworthy, que le Canada a participé dans l'intervention au Kosovo sachant que celleci n'était pas entièrement justifiée en droit mais considérant qu'elle était néanmoins justifée moralement, l'auteur pèse la possibilité d'une acceptation 


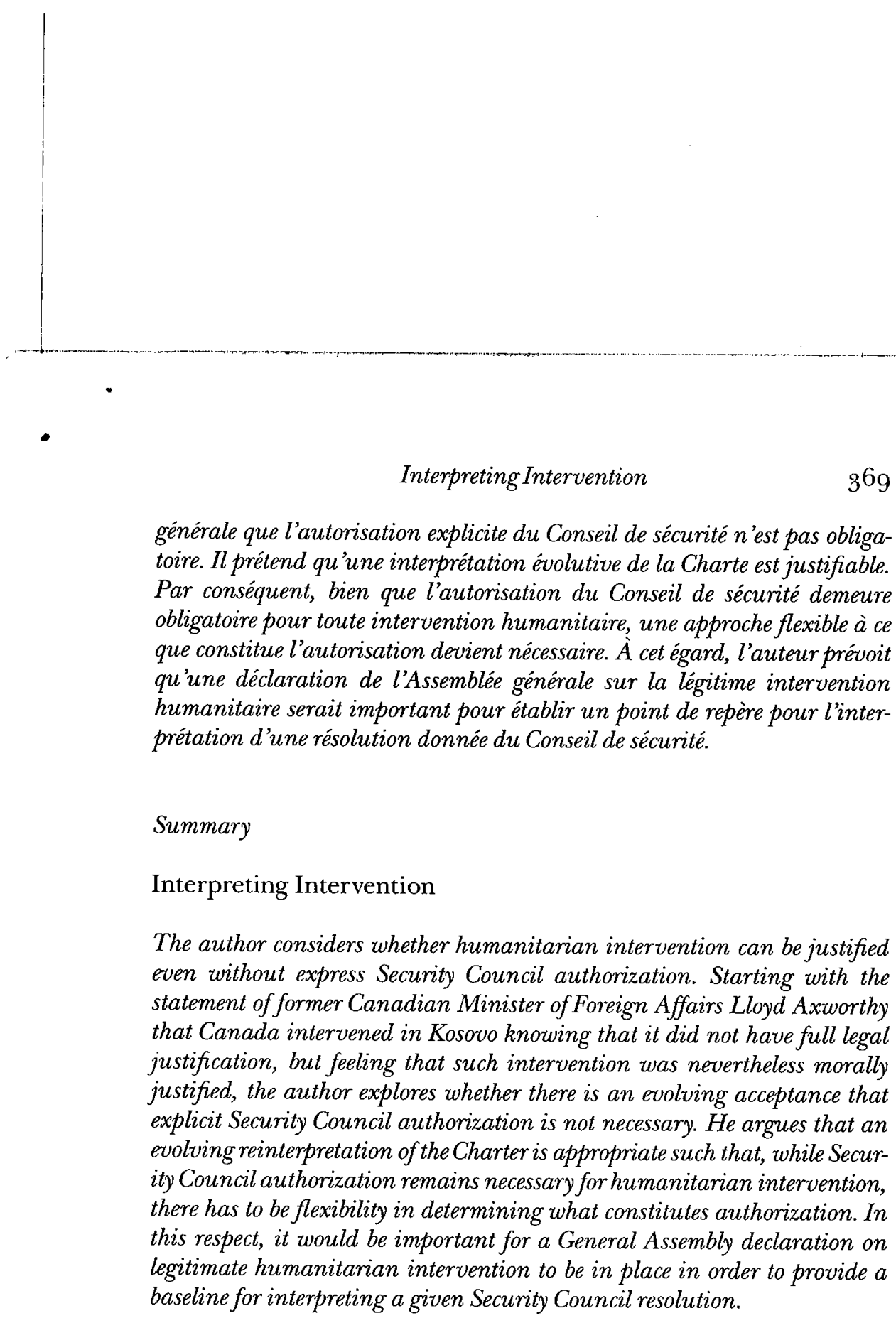

